\title{
From Honour to Subjectivity : Interpersonal violence in Basel 1750-1868 and Berne 1861-1944
}

Maurice Cottier and Silvio Raciti

\section{(2) OpenEdition}

\section{Journals}

\section{Electronic version}

URL: http://journals.openedition.org/chs/1431

DOI: $10.4000 /$ chs. 1431

ISSN: 1663-4837

\section{Publisher}

Librairie Droz

\section{Printed version}

Date of publication: 1 December 2013

Number of pages: 71-100

ISBN: 978-2-600-01776-3

ISSN: 1422-0857

\section{Electronic reference}

Maurice Cottier and Silvio Raciti, « From Honour to Subjectivity : Interpersonal violence in Base 1750-1868 and Berne 1861-1944», Crime, Histoire \& Sociétés / Crime, History \& Societies [Online], Vol. 17, $n^{\circ} 2$ | 2013, Online since 01 December 2016, connection on 22 April 2019. URL : http:// journals.openedition.org/chs/1431; DOI : 10.4000/chs.1431 


\title{
From Honour to Subjectivity: \\ Interpersonal violence in Basel 1750-1868 and Berne 1861-1944'
}

\author{
Maurice Cottier², Silvio Raciti ${ }^{3}$
}

Cet article examine les changements dans les violences interpersonnelles dans les villes suisses de Bâle et de Berne de 1750 à 1944. Il combine des approches quantitatives et qualitatives et repose sur les archives des interrogatoires judiciaires en matière de violence mortelle ou non. On peut repérer une double évolution. D'une part, les bagarres de rue entre hommes, pour des questions d'honneur - - conceptualisées ici comme violence de sociabilité - - qui étaient fréquentes aux XVIII et XIX ${ }^{e}$ siècles, ont diminué au $X X^{e}$. Ce changement fut précédé de la disparition des formes ritualisées de combat, ce qui conduisit les bagarres à devenir plus fréquemment mortelles dans la deuxième moitié du XIX ${ }^{e}$ siècle. D'autre part, on constate la persistance de la violence contre les intimes et les membres de la famille, mais celle-ci prit une qualité nouvelle la différenciant des formes traditionnelles de violence domestique. Le concept de violence fataliste rend compte de ce type nouveau de violence, liée à la subjectivité troublée de ses auteurs. Ces deux évolutions dans les violences interpersonnelles sont dues au développement d'un habitus de classe moyenne dans lequel l'honneur perd sa signification tandis que la subjectivité prend une importance croissante.

The article explores shifts in interpersonal violence in the Swiss cities of Basel and Berne from 1750 to 1944. It combines quantitative and qualitative perspectives and relies on the study of juridical interrogation records of cases of lethal and non-lethal violence. The article identifies two shifts in violent behaviour in Swiss cities. On the one hand, public male on male fighting fuelled by honour, conceptualized as sociable violence, was widespread in the eighteenth and nineteenth century. Yet, it decreased in the twentieth century. The downturn in sociable violence was preceded by a loss of fighting rituals that led brawling to become more lethal in the second half of the nineteenth century. On the other hand, violence against intimates and family members

1 We would like to thank Joachim Eibach, Richard McMahon, and Randolph Roth for their critical reviews that helped to improve the article. We also owe thanks to Susan Kaplan who edited the article with great care.

2 Maurice Cottier is a PhD candidate at the History Department of the University of Bern. His doctoral research project explores violence and sexual crimes in the county of Berne from 1867 to 1944. His research is funded by the Swiss National Science Foundation. Maurice Cottier is also a member of the Institute of Advanced Studies in Humanities and Social Sciences (IASH).

3 Silvio Raciti recently defended his doctoral thesis at the University of Bern with a project on violence and property crimes in the city of Basel from 1750 to 1850 . His doctoral research was funded by the Swiss National Science Foundation, the Dr. H. A. Vögelin Bienz Foundation Basel, and the Dr. Josephine de Kármán Foundation Berne. 
persisted. However, it gained a new quality that differentiated it from more traditional forms of domestic violence. The concept of fatalistic violence captures this new type of violence that was linked to the troubled subjectivity of the perpetrators. Both changes in interpersonal violence were due to the spread of a middle class habitus that fostered the loss of the significance of honour and the increasing importance of notions of subjectivity.

\section{QUANTITATIVE AND QUALITATIVE PERSPECTIVES ON INTERPERSONAL VIOLENCE}

Tn this article, we combine quantitative and qualitative perspectives on two particular shifts in interpersonal violence in the Swiss cities of Basel and Berne. In doing so, we develop the concept of 'sociable violence' and introduce the new concept of 'fatalistic violence'. While sociable violence was present, both, in Basel between 1750 and 1868 and in Berne in the nineteenth century, these crimes markedly decreased from the turn of the century onwards. In contrast, fatalistic violence started to appear around the mid nineteenth century and became prominent in the first half of the twentieth century. We believe that these two shifts are related and are both due to the rise and spread of a middle class habitus.

Our arguments and results are built on the study of juridical interrogation records of cases of felony from the courts of first instance of the Swiss cities of Basel (17501868) and Berne (1861-1944). ${ }^{5}$ The records include 84 murder trials. ${ }^{6}$ Homicides were relatively rare in both cities in the periods examined. At almost no time were there more than three registered homicides per 100,000 inhabitants. Although the absolute number of registered murders for Berne (47 in 84 years) is higher than for Basel (37 in 119 years), considering the population growth, homicide rates were lower in Berne. In the last twenty years of the period under investigation, the homicide rate, based on the court records, was on average below 0.5 per 100,000 inhabitants. ${ }^{7}$ Thus, the quantitative findings from the juridical records of Basel and Berne fit into the European pattern of a decline of violent deaths in the first half of the twentieth century. The general trend in Western Europe was that lethal violence

$4 \quad$ The term 'sociable violence' (gesellige Gewalt) was originally used by the sociologist Inhetveen (1997) who uses Simmels 'The Sociology of Sociability' to explain the role that violence plays for the association (Vergesellschaftung) in contemporary subcultures. See Wettmann-Jungblut (2003, p. 37) for an adaptation of the concept to the early modern period.

5 In the nineteenth and twentieth century, both cities had criminal courts. In contrast, the eighteenth century criminal justice system in Basel is significantly different. At the highest level of jurisdiction, the town council of Basel was in charge of the punishment of felonies but also of some misdemeanours. Staatsarchiv Basel-Stadt (StABS), Protokolle, Kleiner Rat, vol.123-171 (1750-1798) and StABS, Gerichtsarchiv CC Protokoll Ober-Kriminalgericht, vols.1-28 (1798-1870).

6 We excluded murders of newborn babies from our study.

7 The homicide rates computed for this article are not wholly representative since they are based on court registers only which do not include murders where no culprit was found or where the culprit had died. The city of Basel had around 15,000 residents in 1750 rising to approximately 30,000 by 1850. The only exceptionally violent period where the homicide rate averaged 6.9 per 100,000 was during a period of revolution and war around 1800. Again, our calculations only include registered homicide cases. The city of Berne was a little less populated in 1860 with 29,000 people. By the end of the nineteenth century, the city had grown to 50,000 inhabitants and had reached 135,000 by the end of the period under investigation. Gschwind (1977, pp. 172-174); Pfister (1994-2006). 
had been declining probably since medieval times and continued to diminish after 1800 until it reached an all time low in the middle of the twentieth century. ${ }^{8}$

Yet, from a cultural and social point of view, a homicide is not simply a homicide. As shown by cultural history and historical anthropology, the quality of violence needs to be differentiated in order to gain a better understanding of the history of interpersonal violence. By looking at all 84 archived murder cases, it is possible to identify certain qualitative aspects. Furthermore, we obtain a deeper insight into the changing social and cultural practices of violent actions in the investigation period by adding cases of non-lethal crimes. At our disposal for in-depth analysis are four samples from Basel's lower and higher courts covering the years from 1750 to 1850 (1755-1759, 1798-1802, 1826-1830, and 1845-1849) providing information about every violent crime that was reported to the authorities. The samples contain a total of 377 cases. $^{9}$ For Berne, we are able to characterize (almost) all the 163 cases of violent crimes that were judged by the criminal court between 1861 and $1944^{10}$ plus in-depth information from criminal court records from 1861-1873 and 1893-1927. ${ }^{11}$

A threefold perspective guides our reading of the cases. First, we identify the participants' age, sex, and profession and thereby build a profile of individual offenders. Second, we focus on the timing and location of the violent event itself and explore the participants' actions immediately before, during, and after a violent crime. Looking at behavioural patterns leads to a third perspective: how the participants narrated their own behaviour and that of others. The story matters too. The analysis of the narratives provides important information about how the participants made sense of their actions and the events they experienced. In this sense, the story not only informs us about the events. It is a cultural product and therefore a historical fact on its own. ${ }^{12}$

The threefold perspective provides a distinctive picture of lethal interpersonal violence in Basel and Berne. Hence, homicides did not just simply decline in the early twentieth century. Their character changed too.

8 Most research based on homicide rates employs Elias' civilizing process as theoretical background. See Spierenburg (2008, pp. 174-181, 223-224); Muchembled (2012, pp. 211-242, 301-302). Reliability, validity, and interpretation of homicide rates are issues of controversy in the field as they may be biased by source material and influenced by other factors (e.g. level and quality of health care or nutrition). See Schwerhoff (1991, pp. 282-286) and Roth (2009, pp. xii-xiv, 12). The overall homicide rate for Switzerland is only calculated from 1877 onwards; see Bieri (1998); Eisner (1997, pp. 49-56). For Europe and the USA see Gurr (1981, pp. 325-326) and Roth (2009, pp. 297-299).

9 StABS, Criminalia, several chests, 1755-1759; StABS, Gerichtsarchiv HH 1, Korrektionelle Fälle, Akten, vol. 8-52, 157-185 (1826-1830, 1845-1849); StABS, Gerichtsarchiv HH 2, Kriminalgerichtsakten, vols.1-21, 230-273, 330-344 (1798-1802, 1826-1830, 1845-1849); StABS, ,Straf und Polizei ‘ C 19, ,Mord und Totschlag' (1798-1802); StABS, ,Straf und Polizei ' C 24, ,Körperverletzung, Schlaghändel, Unfugen, Eigentumsbeschädigung, Nachtfrevel, Misshandlungen, Nachtlärm, Ruhestörer, Belästigungen“ (1798-1802).

10 Staatsarchiv des Kantons Bern (StAB), BB 15. 4. (1861-1944), ,Mord, Mordversuch, Totschlag, Totschlagversuch, Misshandlung, Körperverletzung, Raufhandel`. There are nine cases missing from the $1860 \mathrm{~s}$.

$11 \quad$ StAB BB 15. 4. (1861-1873, 1893-1827), see Cottier (2009a, 2009b).

12 For this argument in literary studies see Belsey (2010). 
Table 1: Homicides in Basel 1750-1868 and Berne 1861-1944: Total and by categories. Based on the court records as listed in footnotes 2 and 7. The category 'strategic' denotes homicides aimed at material or non-material benefits, as hold-up murders and other homicides where the perpetrator somehow intends to benefit from the death of his victim (e.g. murder to avoid paying a debt; a lover killing a wife's husband so he can marry her). The other categories are explained in the text.

\begin{tabular}{|c|c|c|c|c|c|c|c|c|c|c|c|c|}
\hline & \multicolumn{6}{|c|}{ Basel (full survey 1750-1868) } & \multicolumn{6}{|c|}{ Berne (full survey 1861-1944) } \\
\hline & 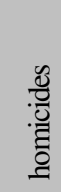 & $\frac{0}{\frac{\pi}{\pi}} \frac{\pi}{8}$ & 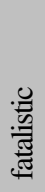 & 总 & 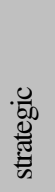 & $\frac{\bar{\Phi}}{\bar{\Xi}}$ & 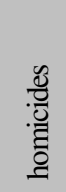 & $\frac{\frac{0}{2}}{\frac{\pi}{8}}$ & 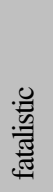 & 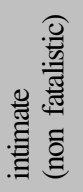 & 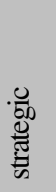 & $\begin{array}{l}\bar{\Phi} \\
\bar{z}\end{array}$ \\
\hline $\begin{array}{l}1750- \\
1799\end{array}$ & 10 & 3 & 0 & 3 & 3 & 1 & & & & & & \\
\hline $\begin{array}{l}1800- \\
1868\end{array}$ & 27 & 13 & 0 & 8 & 4 & 2 & & & & & & \\
\hline $\begin{array}{l}1861- \\
1899\end{array}$ & & & & & & & 26 & 20 & 2 & 3 & 1 & 0 \\
\hline $\begin{array}{l}1900- \\
1944\end{array}$ & & & & & & & 21 & 4 & 11 & 0 & 6 & 0 \\
\hline Total & 37 & 16 & 0 & 11 & 7 & 3 & 47 & 24 & 13 & 3 & 7 & 0 \\
\hline
\end{tabular}

Sociable violence was present in Basel in the second half of the eighteenth century and was the most prominent type of lethal violence, both in Basel between 1800 and 1868 and in Berne until the turn of the century. However in the first half of the twentieth century, sociable violence occurred far less often than in the last forty years of the nineteenth century. In fact, the last sociable homicide in Berne was reported in 1911; the last of 66 cases of sociable violence that was severe enough to be judged by the criminal court dates from 1913. Moreover, on the level of the courts of lower instance, reports of assault and battery declined as well. ${ }^{13}$ Hence, although sociable violence was probably not completely absent in Berne, it did not cause any deaths or severe injuries in the last 20 years of the period of investigation. It is striking how radically this type of violence declined in Berne after it had been responsible for the vast majority of the killings in the forty years before the turn of the century. ${ }^{14}$

13 Therefore, the decline of sociable violence is not due to a change of the legal system. We counted assault and battery cases (Drohung, Misshandlung, Tätlichkeit, Raufhandel) for every fifth year. In 1880,15 persons living in the county of Berne (including the city of Berne and surrounding rural communities) were accused of assault and battery; in $1885: 15 ; 1890: 15 ; 1895: 25 ; 1900: 11$; $1905: 16 ; 1910: 12 ; 1915: 7 ; 1920: 10 ; 1925: 6 ; 1930: 4 ; 1935: 6 ; 1940: 2$. StAB XV 1123 and 1124. See Cottier (2009b, p. 13).

14 Although the "[d]runken-brawl homicide rate" had decreased in Chicago since the turn of the century, sociable violence was still present as lethal brawls were responsible for almost 10 percent of all homicides in the city by 1920 (Adler 2006, pp. 42-43). Historical research for the period 1920 to 1960 seems to be sparse. This makes it difficult to contextualize our findings on declining sociable homicides in Berne. 
The findings from Basel and Berne follow the broad pattern seen in Western Europe. Decreasing lethal male-on-male fighting was mainly responsible for a considerable drop in the overall homicide rates. What persisted was violence against intimates and family members. ${ }^{15}$ However, the study of juridical records from Berne indicates that incidents in this category underwent significant changes at the end of the nineteenth and the beginning of the twentieth century.

We believe that the concept of fatalistic violence gives new insight into the changing faces of interpersonal violence against intimates and family members in the modern era. Although fatalistic violence overlaps to a large extent with intimate violence, the two concepts are not identical. We refrain from employing the common categories of domestic, family, or intimate violence because they also cover incidents with more traditional forms of violence. These definitions do not allow us to account for the distinctive new features that fatalistic violence exhibited in Berne at the turn of the century. Therefore, we separate 14 homicides of family members, intimates, and in the household that do not exhibit the features of fatalistic violence. In Berne in the first half of the twentieth century, fatalistic violence (to a large extent, but not exclusively, against intimates and family members) caused the most deaths. The trend is the same for non-lethal violent crimes. In Basel, the first (non-lethal) incident of fatalistic violence during our period of investigation occurred in 1840 . But fatalistic violence remained very rare in Basel up to 1868 - there were only 3 such cases. In Berne, 8 fatalistic crimes were reported before 1900, the number rose to 28 in the first 44 years of the twentieth century. None of the reported fatalistic crimes from Basel up to 1868 ended in death. The same counts for Berne until 1898. This article explores this rise in fatalistic violence and investigates how it relates to the decrease of sociable violence over time. ${ }^{16}$

\section{SOCIABLE VIOLENCE}

\section{On the character of sociable violence}

In April 1755, 50-year-old city official Onophrio Merian went for a stroll outside the city of Basel. He bought fish and drank some wine in the tavern. On his way home, he was insulted by two master butchers. At first, he continued on his way but then decided to confront the butchers and demand satisfaction. He asked the 44-year-old Niclaus Bientz and the 40-year-old Lucas David why they had called him a son of a bitch. After some more insults, Bientz grabbed Merian by the scruff of his neck. Merian defended himself with his stick and when he lost it in the fight he drew his rapier. At this point, David joined the fight to defend his companion Bientz. Merian did not use the rapier to sting or cut. In the end, he lost his rapier too and he fled home. Bientz kept Merian's rapier, stick, and hat as trophies. A few days later, Merian pressed charges against the two butchers and went out in the city looking for testimonies from witnesses to the fight. ${ }^{17}$

\footnotetext{
15 Spierenburg (2008, pp. 174-181, 223-226); Muchembled (2012, p. 211-242, 301-302).

16 We exclude hold-up murders and other strategic murders from further analysis.

17 StABS, Criminalia Lade 14 B Nr. 24.
} 
Historians have used cases similar to the one above to point out the importance of honour in late medieval and early modern European societies. Drawing on Pierre Bourdieu's Outline of a Theory of Practice, cultural history and historical anthropology highlight honour as a social fact. In late medieval and early modern European societies, it was relevant in everyday life. Honour as a social fact was crucial, both symbolically and materially and was important not only to the nobility but to every stratum of feudal society.

Honourableness not only included the reputation or credibility of a person but also that of his group or family. Even the houses, shops or other properties were part of a person's honour. ${ }^{18}$ According to Bourdieu, honour is "a permanent disposition, embedded in the agents' very bodies in the form of mental dispositions, schemes of perception and thoughts". Moreover, honour is strictly gendered: while female honour is considered to be passive, male honour needs to be actively asserted. ${ }^{19}$

Research has proved that from the late medieval period onwards, fights between men like the one between Merian, Bientz, and David happened in the public spaces, such as the inns, taverns, market squares, and streets of Swiss cities. ${ }^{20}$ In public, men had to be extremely aware of challenges to their honour and had to be ready to answer any test. In his study on Kabyle people in Algeria, Bourdieu describes this behaviour as a "game of honor". He explains: "[I]n the game of honor, challenge and riposte alike imply that each player chooses to play the game as well as he can while assuming that his adversary is capable of making the same choice". Hence, in this game, honour is created interactively and dialectically between virtually equal men. ${ }^{21}$ To challenge someone's honour by insulting him does not simply dishonour the insulted man but invites him to answer and offers him a chance to prove his honourableness to others and himself. ${ }^{22}$ The game of honour was also played in Western Europe. Often, it led to violent outbursts. Yet, violence was an integral and accepted part of the game. In the context of honour, violence was a legitimate way to communicate. ${ }^{23}$ In pre-modern Europe the privileged space for the game of honour was the sociability of the taverns. ${ }^{24}$ This is why we speak of 'sociable violence'.

In his essay The Sociology of Sociability, Georg Simmel distinguishes sociability (Geselligkeit) from society (Gesellschaft). In acts of sociability, people meet as equals. Stressing the importance of equality, Simmel emphasizes that every social stratum tends to create its own sociability. Due to its "democratic structure", "a pure interaction, free of any disturbing material accent", can unfold. ${ }^{25}$ While society is real life where conversations and interactions are driven by material or ideological interests, sociability, by contrast, is an "artificial world" where people speak to each

Muchembled (1989); Schwerhoff (1991); Schreiner, Schwerhoff (1995); Dinges (1995); Walz (1992).

19 Bourdieu (2004, p. 15).

20 See Simon-Muscheid (1991) for late medieval Basel.

21 Bourdieu (2004, p. 12).

22 Bourdieu (2004, p. 11).

23 Eibach (2003, pp. 214-215).

24 Frank (1995, p. 336); Eibach (2003, pp. 241-248); Walz (1992, p. 224); Spierenburg (1998, p. 103); Töngi (2004 pp. 178, 183).

25 Simmel (1949, p. 257). 
other and interact with "no ulterior end, no content, and no result outside itself". ${ }^{26}$ In the "shadow world" of sociability, where there is "no friction, because shadows cannot impinge upon one another", society "is played". ${ }^{27}$ Notwithstanding sociability's game-like and artificial character, it is not completely detached from society. It is "a symbol of life". ${ }^{28}$ Therefore, sociability "represents aesthetically" what "the seriousness of realities otherwise demands". Sociability is the "play-form [...] for the ethical forces of concrete society." 29

Simmel was not thinking about brawling men when he theorized sociability as a play-form of society. His examples consist of small talk and flirting. Yet, Simmel's concept of sociability helps to better understand the cultural and social meaning of 'sociable violence'. Brawls were not only sociable because they took place in taverns. They were also sociable because of the game-like character of violence. Hence, the game of honour was privileged to be a part of the sociable world. Therefore, Simmel's view on sociability needs to be corrected in one respect: In the artificial world of pre-modern European sociability, shadows could easily impinge.

The particular narratives of sociable violence mirror the game-like and interactive character of sociable violence. Reading the protocols, one can closely follow the interaction. In their stories, brawlers recounted in detail the laterally, exchanged insults, blows, and strikes. The protocols inform us that, in taverns, inns and on the streets at night, men reacted violently to pointless insults but also, strongly tended to insult others. The causes that triggered fights were rather trivial. Men who fought each other were often complete strangers. Even when the competitors were acquainted, only in a very few cases were arguments at the workplace carried over into the sociable world.

Hence, arguing and fighting were free from material accent. ${ }^{30}$ Often, there was no ulterior end and no result outside itself. In other words : fighters fought to fight. Men who wanted to start a fight were trying to find a partner. Thus, sociable violence was essentially interactive and dialectical. Men provoked each other with gestures and words. If somebody responded, a verbal dispute could easily transform into wrestling and lateral blows. The transition from verbal to physical competition was very smooth. The sociable character of an argument, however, did not change when it turned violent. Both insults and blows were part of playing. Fighting prolonged the argument rather than marking a clear difference. The fight was intended to demonstrate physical strength and toughness. Violence also had such a strong symbolic power because it was physical. The goal was to triumph symbolically by physically defeating the opponent. Men quarrelled and fought for the authority over

\footnotetext{
$26 \quad$ Simmel (1949, pp. 254-255).

27 Simmel (1949 pp. 258, 260).

28 Simmel (1949, p. 261).

29 Simmel (1949, p. 260).
}

30 The German-speaking literature on violence in the early modern period argues that there was often a hidden material conflict behind violent activity (e.g. Dinges (1994, pp. 412-414), Walz (1992, p. 250) and Gerd Schwerhoff's contribution in this collection). Recently, research started to distinguish 'proxy conflicts' and 'competitive games'. See Ludwig (2011, pp. 377-380). The latter correspond roughly to our concept of sociable violence. The marginalization of violence and the growing social complexity in the late early modern period make it easier to differentiate in the nineteenth century between sociable violence (as competitive games in peer groups) and violent acts as proxy conflicts for other disputes at the workplace or in the context of neighbourhood. 
the sociable world. Yet, most of the time, defeat and victory were situational and only relevant in the moment.

We argue that sociable violence can best be understood as a game or symbolic interaction. In the period under investigation there must have been thousands of violent confrontations in the sociable space that ended harmlessly and therefore were never reported to the authorities. In their sociable time, men could buy drinks, dance with girls, and play card games. They could prove their courage and strength either by insulting others or by reacting harshly when insulted. Directly confronting others was only one way to prove strength. Supervising the tavern was another way. As much as men made fun of companions, insulted people, broke window panes, grabbed each other by the scruff of the neck, disturbed the dance, or annoyed the innkeeper, they also helped to police the sociable space by intervening when somebody acted rudely. Both challenging and guarding the order were means to show strength and honour. Systematically, this antagonism led to frictions and violent fights.

Brawlers not only fought to demonstrate their honour to themselves and to those who challenged them but also to the bystanders. A brawl was a sociable rather than a personal affair. The audience was involved. To be considered legitimate, the brawls had to follow certain ritual patterns. There were rituals that allowed the public to interfere when limits were breached. Sociability was quarrelsome but at the same time ritualized. According to Bourdieu, the "eyes of the group" arbitrate the game of honour which has certain ritual patterns that must be respected. ${ }^{31}$ Thus, rituals contained violence. Historians have pointed out the ambiguous character of honour, since it both favoured and contained violent behaviour. ${ }^{32}$ In sociable violence, the killing of the opponent was never an aim. But, of course, with alcohol and high emotions involved, things could get out of hand. Hence, tavern brawls could end in death or severe injury. However, lethal endings were accidents. Precisely because brawling was hazardous, it was a privileged way of showing honour.

Combining Bourdieu's concepts of honour with Simmel's concept of sociability helps in understanding the frequent violent outbursts in late medieval and early modern societies. To some extent, sociable violence aesthetically produced the ethics of an honour society. Insulting, quarrelling, and fighting were ways to generate honour. The privileged space for this game was sociability where men met as equals. Rather than being slaves to their impulses and emotions, pre-modern men fought for honour by choice. As much as men responded resolutely to insults, they also deliberately challenged others. Men, especially when drunk, certainly reacted impulsively to defamations as Elias' theory on the Civilizing Process suggests. ${ }^{33}$ Yet, in an honour society, such strong emotions were culturally generated, framed, and publicly supervised.

\section{The loosening of fighting rituals}

As mentioned above, the last case of sociable violence from Berne that was severe enough to be judged by the criminal court dates from 1913. Hence, in the long term Berne followed the Western European pattern of declining male-on-male

31 Bourdieu (2004, p. 13).

32 Dinges (1995, p. 52); Walz (1992, p. 223).

33 Elias (1982a, pp. 191-205). 
fighting. Sociable violence was certainly not completely absent in Switzerland in the interwar period but the radical decline of lethal and severe sociable violence in the Swiss capital was extraordinary.

Yet, the study of the juridical records from Basel and Berne paradoxically shows that sociable violence was more lethal in Berne between the 1860s and the 1910s than it was in Basel between 1750 and 1868. This is especially so for the 1870s. ${ }^{34}$ Increasing numbers of sociable homicides in the 1860s indicate that Basel might have followed the same pattern as the nineteenth century came to an end. Furthermore, the register of the criminal court of Berne shows that sociable violence was less lethal in the city in the $1850 \mathrm{~s} .{ }^{35}$

On the basis of cases of lethal and non-lethal sociable violence, we will discuss this paradox in the context of a changing society in which honour started to lose its importance as a social fact. We argue that the disintegration of the old honour society in the course of the nineteenth century led to a loosening of fighting rituals that at first caused the increase of lethality in sociable violence. However, in the long run, the same disintegration was also responsible for the overall decline in sociable violence after 1900 .

Whereas around 1500, public violence in the context of honour was common in all social strata, ${ }^{36}$ Eibach points out that, in Frankfurt on Main by the middle of the eighteenth century, patricians and upper-middle class burghers no longer settled their honour disputes violently in public. During the second half of the eighteenth century, this tendency persisted. Furthermore, Eibach observes a loosening in rituals as fighting predominantly became a matter of men from the middle and lower stratum. ${ }^{37}$ Although honour still played an important role in nineteenth century Swiss cities, more and more inhabitants were choosing to bring their honour disputes to court rather than settling them violently. Throughout the century, the courts of Basel and Berne dealt with a high number of libel and slander cases. ${ }^{38} \mathrm{~A}$ survey of the plaintiffs in private actions from Basel shows that growing numbers of journeymen,

34 Although the homicide rate was higher in Basel around 1800, we do not count this short period because it was a time of revolution and war. At the time, the French military was stationed in Basel and members of the troops were heavily involved in the killings.

35 Due to missing court records, it is not possible to characterize the murders from the 1850 s. However, even given the possibility that all homicides in the county of Berne were sociable homicides and all happened within the city, the rate for the 1850 s (0.6) would still be significantly lower than the sociable homicide rates for city in the 1870s (2.9). Since the register informs us that one of the Bernese murderers from the 1850s was a woman, the sociable homicide rate for the 1850 s would probably be even lower.

36 Schuster (2000 pp. 135-136).

37 Eibach (2003, pp. 203-286); Eibach (2009, pp. 198-199).

38 It is not possible to exactly translate the Swiss legal terminology with the terms libel and slander. While libel is a written defamation, slander is gestural or verbal; see Bouvier (2011, pp. 654655,1033-1034). The Bernese penal code from 1866 also distinguished written from verbal defamations since the former were dealt with by the criminal court, while the lower courts dealt with the latter. Notwithstanding this hierarchy, the terminology of the Bernese penal code does not differentiate between written libel and verbal or gestural slander but between 'Ehrverletzung' (or 'Injurie') and 'Verläumdung'. The first defames a person's personal attributes or his or her behaviour in general; hence, his or her honour. The second refers to a specific single action of a person, that, if it were true, would be culpable; see Strafgesetzbuch für den Kanton Bern (1866, p. 56). Thus, both, 'Ehrverletzung' and 'Verläumdung' can be written or verbal and, therefore, can be translated with either libel or slander. However, we only include 'Ehrverletzung' and 'Injurien' in our further analysis. 
day labourers, and domestic service personnel filed cases of insult before the court. ${ }^{39}$ Also in the upper stratum, honour was still an important attribute, ${ }^{40}$ although, unlike in Switzerland's neighbouring countries, the duel never established itself as a distinct form of violent dispute settlement among the Swiss Bourgeoisie. ${ }^{41}$

In the nineteenth century, however, violence could still play a part in honour disputes. Violence in the context of honour did not disappear. Yet, it was increasingly marginalized as a social practice. In nineteenth century Basel and Berne, the violent game of honour became almost exclusively a practice of men belonging to the lower social stratum. While in eighteenth-century Basel a significant proportion of the participants were master craftsmen and city officials, opponents in the nineteenth century were predominantly journeymen, apprentices, day labourers, and domestic service personnel. The same was true for Berne, but at the end of the nineteenth century, with the advancing structural change in the urban economy, construction and factory workers crowded out the 'old' professions. ${ }^{42}$ Sociable violence became a matter for men between 20 and 35 years of age. ${ }^{43}$ Moreover, not only were the social stratum and cohort of the participants narrower than in previous centuries, fighting was also increasingly concentrated in the late evenings and the weekends. ${ }^{44}$ Thus, while social interaction in general became more peaceful, this form of sociable interaction did not. By the 1870s and 1880s, 14 out of 16 murders in Berne were caused by sociable violence. The sociability of youths from the lower stratum remained a space where the 'game of honour' was played in a violent fashion.

It is impossible to tell if the actual number of brawls declined in the course of the nineteenth century as sociable violence was marginalised in a society in which non-physical forms of conflict settlement increased. But by comparing the court records from Basel and Berne, it becomes clear that fighters in Berne used knives in a more lethal fashion than the brawlers from Basel. However, the records

39 1755-1759: 137 cases; $1798-1802: 112 ; 1826-1830: 379$ and 1845-1849: 153 . The decrease from the 1820 s to the 1840 s ensued from amendments of the criminal law with effect from 1847 . The percentage of cases filed by persons without citizenship of the city increased from 15\% (3\% by resident journeymen and $12 \%$ by non-resident people of the middle and upper classes) from 1755-1759 to $33 \%$ (journeymen: $20 \%$, domestic service personnel: $9 \%$, day labourers: $4 \%$ ) from $1845-1849$. These figures do not include cases involving security forces. Compare also Goldberg (2010) who stresses the importance of honour in German society between 1871 and 1914 and asserts that defamation litigation spread to the lower classes.

40 Arni (2004, pp. 215-224); Raciti (2006, pp. 87-89).

41 Frevert (1998); Ludwig, Krug-Richter, Schwerhoff (2012).

42 For Basel see the representative case example in the text and Raciti (2006, pp. 53-57); for Berne compare Cottier (2009a, pp. 36-38, 2009b, pp. 28-30).

43 In Basel, the percentage of brawlers that were below 30 years of age increased from 48 (1755-1759) to 69 (1826-1830) and 87 (1845-1849); also see Raciti (2006, pp. 50-59). This high percentage of young men participating in sociable violence continued in the county of Berne (including the city of Berne and surrounding rural communities) where between 1861 and 1873 when $78 \%$ of all participants were between 20 and 35 years old. Between 1893 and 1927, 75\% of all participants were between 18 and 31 years old; see Cottier (2009a, p.36 and 2009b, p. 23).

44 In Basel, the percentage of sociable fights that were after $6 \mathrm{pm}$ increased from 52 (1755-1759) to 68 (1826-1830) and 78 (1845-1849); in the county of Berne (including the city of Berne and surrounding rural communities), the percentage of sociable fights that were after 8 pm grew from 75 (18611893) to 94 (1893-1927). In Basel, the percentage of sociable fights that took place on Saturdays and Sundays rose from 28 (1755-1759) to 45 (1845-1849); in the county of Berne, they increased from 58 (1861-1893) to 85 (1893-1927); for Berne see Cottier (2009a, p. 38, 2009b, p. 25). 
from Basel's courts, both of lower and higher instance, show that brawlers already increasingly used pocket knives and other instruments such as sticks, tools, and stones or other items at hand to injure their opponents. In the eighteenth century, weapons or other dangerous instruments were hardly employed. Brawlers - like Merian from our first case example - predominantly used rapiers not to stab or cut, but only to hit the opponent with the flat of the blade. The situation changed after 1800. Although brawlers risked being dangerously stabbed during a fight throughout the whole period of investigation, the chances increased during the first half of the nineteenth century.

With a definition of a severe injury as injury causing death or requiring more than ten days of recovery, we can compare the four samples from Basel. In the 1750s only $8 \%$ ( 3 out 36 ) of the cases ended in a severe injury; from 1798-1802, it was $28 \%$ (11 out of 38 ); in the $1820 \mathrm{~s}, 36 \%$ ( 8 out of 22 ); and in the 1840 s, $41 \%$ (25 out of 60 ). This roughly corresponds to a rising share of brawls in which instruments were used: in the 1750s in 17 out of 36 cases (39\%) instruments were employed. Subsequently, the share rose to $45 \%$ (17 out of 38) from 1798-1802 and to 64\% in the 1820 s (14 out of 22). Finally, it declined to $58 \%$ in the 1840 s (37 out of 60 cases).

Because of the different data, it is not possible to exactly compare the situations from Basel and Berne. The data from Berne is drawn from the criminal court only, which dealt solely with sociable violence that caused death or injuries requiring at least twenty days recovery time. However, the trend for brawlers' injuries to be caused by instruments, again mainly pocket knives, continued in Berne throughout the last four decades of the nineteenth century and into the 1910s (in the 1860s, all 8 severe injuries were caused by instruments ; in the 1870 s, 10 out of 21 ; in the 1880 s, 5 out of 7 ; in the 1890s, 9 out of 12 ; in the 1900s, 12 out of 13 ; in the 1910s, all 3). ${ }^{45}$

More importantly, in Berne in the second half of the nineteenth century, brawlers started to stab in a different fashion. In the samples from nineteenth century Basel, knives were mostly aimed at the extremities - most injuries registered were to the arms and legs. In Berne, brawlers no longer just aimed at their opponent's extremities but at the head, neck, or torso. Consequently, sociable violence ended lethally more often. ${ }^{46}$

Most of the time, pocket knives were only used stealthily from defensive positions when brawls became lopsided and defeat was imminent. Often the witnesses to the fight did not even notice the weapon. Hence, there were no actual knife duels. Stabbing did not belong to the ritual patterns of the game of honour. Its increasing use in the middle of the nineteenth century can be read as the first sign of an ongoing loosening of rituals. The disintegration of the ritualized game of challenging and riposting becomes even more obvious when one closely examines some of the knife incidents that occurred after the turn of the century. In 1903 a tavern brawl broke out between the two Bechthold brothers. An acquaintance of the innkeeper, a man named Häntsch, intervened and forced one of the brothers, Rudolf, and his two friends, Szvozil and Schmalz, to leave. However, the three troublemakers waited outside on the street to finally settle the argument with Gerhard Bechthold. Later

45 These numbers exclude two shootings in sociable contexts where nobody was severely injured. However, as they classified as a murder attempt, they were judged by the criminal court.

46 In Berne, almost half of the stab victims who were seriously injured between 1861 and 1913 died (14 of 30). 
on, when Häntsch accompanied Gerhard out into the street, the dispute restarted and Häntsch and Schmalz began to fight and both men ended up wrestling on the ground. Szvozil who was uninvolved in the fight decided to help his friend. Up to this point, the incidents in the tavern and on the street had followed the traditional ritual patterns of sociable violence. What gives this case a special quality is the fashion in which Szvozil intervened: he pulled out his knife, stepped towards the wrestlers, and stabbed Häntsch in the head without warning. ${ }^{47}$

Although most stabbing continued to be a defensive act, cases where knives were used offensively became more numerous, especially after 1900. Finally, another aspect indicates that sociable violence was increasingly losing its traditional ritual patterns. Starting in the late 1870s, handguns were used on the night-time streets. Their use indicates a further loosening of the ritual patterns towards the end of the nineteenth century. Revolvers shortened the game compared to the physical competition. To some extent, sociable violence was rendered meaningless by the use of revolvers. Although less obvious, the same applies to the increased use of knives or other instruments. Embedded in a culture of honour, defeating a man by physical strength was honourable; stealthily stabbing him or shooting him from a safe distance was not. We argue that the fact that knives were used more dangerously in sociable violence is due to a loosening of rituals in the second half of the nineteenth century and the early twentieth century. Fighting became more and more capricious. Although the game of challenging and riposting, where gestural and verbal provocation led to wrestling and blows, was still present, the ritual procedure became fragmentary. This made sociable violence both more dangerous and meaningless at the same time. Without rituals there was no honour; and without honour there were no rituals.

\section{FATALISTIC VIOLENCE}

\section{On the character of fatalistic violence}

Towards the end of the nineteenth century, at the time when the ritual patterns of sociable violence started to disintegrate, another type of violence became increasingly common. We characterize this type as 'fatalistic violence'. Whereas lethal endings to brawls were accidents, deaths caused by fatalistic violence were not. Two examples from Berne illustrate this phenomenon.

On the evening of 9 July 1911, a Saturday, the 25-year-old journeyman cobbler Albert Moser visited a dancehall near to where he lived. There, "a lad", who Albert could not see, shouted at him that "Augustine Fellmann was dancing with somebody else in the other room." After hearing this voice, Albert left the dancehall early and went to the house of his former sweetheart's family. He hid silently in the attic and waited for the return of his beloved. When the 18-year-old Augustine Fellmann returned from the dance, Albert came down from the attic and surprised her in her room. He held a revolver in his hand and told Augustine that "now [they] should die with each other". He then shot the girl twice in the back. During the hearing, he said that after he had committed the crime he tried to kill himself but "lost courage"

StAB BB 15. 4. 17479680. 
to do so. Albert stated that he did not act in a state of "craziness" but that he was "extremely excited". Augustine was taken to hospital and survived the shooting.

Albert told the examining magistrate that he had liked Augustine "ever since he was a boy". Approximately a year before the murder attempt, Albert asked Augustine if she wanted to become his lover. For a while, the relationship went well but there was an underlying instability, especially since Augustine's mother disliked Albert's low social status. Under her mother's influence, Augustine broke up with Albert. Although they continued to see each other secretly, Albert became increasingly worried that Augustine was cheating on him. A week before the murder attempt, while they were on their way home from a dance, he told her that he would do "something stupid" if she were to start a relationship with another man. By the time they reached the Fellmann home, they had made up again. However, the trouble was not over. Augustine's sister gave the two lovers an unpleasant welcome as she accused them of making her mother deeply unhappy and suicidal because of their ongoing relationship. This was a crucial moment for Albert. He later recounted: "Up to this moment, I believed that everything would turn to good account. But now, I started to realize that a marriage between Augustine and me would be impossible since the parents would never give their permission. I became very despondent because I loved the girl very much; and she loved me too." In the course of the following week, Albert sent Augustine a letter asking her to grant him a "rendezvous" on Saturday. As she did not show up Albert thought "now, everything is over". However, Albert found it difficult to define exactly the moment when he made up his mind to kill his beloved. Later in the interrogation, Albert confirmed: "It is correct that I had already decided on Friday night to kill Augustine Fellmann and myself." It was also on that Friday, when he bought a revolver and six cartridges. ${ }^{48}$

In the same July of 1911, the 39-year-old Emil Aebersold, a door-to-door salesman, went for a walk with his three boys. When they reached a forest, Emil, who was in tears, pulled out a gun and shot his eldest son in the head. The two other boys ran away, but Emil called his youngest to come back. He told him that he must "want to go to heaven to meet the little angels" and shot him too. Emil could not find his third son and, as a result, he took a train to get to his daughter who, at the time, was spending her school holidays in a small village near Berne. Emil was arrested by the police when he got off the train. During his interrogation, he told the examining magistrate that he had two cartridges left when he got off the train - one for his daughter and one for himself.

Emil was not sure if he had publicly announced his intention to kill his children and himself. "A habitué at the Café Amthaus lately told me that I had announced this intent at the café. I do not remember these events; I heard of others that I have said this. Probably, I was drunk at the time". Emil continued: "It is correct that I recently thought about killing my four children and myself. But I was able to put these thoughts away once my depressed mood was over". He further explained that he had already thought about it earlier that year: "In February [...] after a severe quarrel with my wife, I thought about drowning the children and myself in the river if our relationship did not turn to the better. To my knowledge, I never thought about killing my wife". On 19 July, Emil bought himself a revolver to be ready to kill himself and his children. "I thought that if my wife drove me crazy again, I

StAB BB 15.4. 1920949. 
would carry out my intent". At noon, Emil returned to the family's apartment. He immediately got upset because his wife had not cooked supper and, instead, was chatting to a neighbour. "Hence, I immediately thought that my wife is asking for trouble again. This distressed me so much that I thought: 'Now, it's over.' Without saying a bad word" he asked his boys to join him to pick cherries in the forest. ${ }^{49}$

At first sight, the perpetrators' behaviour might seem to be too psychological or even too psychopathological to be dealt with by cultural history. However, these cases are not distributed evenly between 1750 and 1944 but are concentrated within the last 50 years of our investigation period. This fact makes the phenomenon interesting for historical research. Of course, the two case examples above are different in many ways. This especially applies to the social relationship of the perpetrator and the victim, which is commonly used in historical research to classify interpersonal violence. It does not make sense to treat fatalistic violence as a practice of a distinct social group. Although most perpetrators belonged to the lower stratum, fatalistic violence was not exclusively committed by the poor. Fatalistic perpetrators were cobblers or small-scale salesmen, knitters, hairdressers or Italian miners. However, they were also middle class housewives, constructions site supervisors, tradesmen or Russian students. Unlike sociable violence, neither perpetrators of fatalistic violence nor their victims were exclusively male, although men committed the vast majority of the crimes. Furthermore, neither perpetrators nor their victims belonged to a certain cohort. Yet, the two case examples also show striking similarities, which mark a significant difference to sociable violence and to other more traditional types of interpersonal violence in the family, between intimates or in a household. Studies on the early modern period show that spousal murders were either impulsive or instrumental..$^{50}$ Especially before 1900, the majority of cases of intimate and family violence in Basel and Berne do not meet the conditions to be classified as fatalistic. When a drunken husband, on his return home from the tavern, quarrelled with his wife over money or household duties and then beat her to death, the patterns of the crime differ significantly from a fatalistic murder. Spierenburg labels such cases as "hierarchy-related punishments that got out of hand". ${ }^{51}$

Fatalistic crimes distinguish themselves from all other types of violence by being neither instrumental nor ritual and neither rational nor impulsive.$^{52}$ In order to gain a better understanding of this type, we identified four features that together define fatalistic violence. First, the perpetrator of fatalistic violence felt strong emotions towards his or her victim. This passion was fuelled either by feelings of love or hate, or both simultaneously. The emotional relationship could be completely unilateral and by no means had to be mutual. Therefore, although victims of fatalistic violence were predominantly lovers, spouses and the perpetrator's own children, they also included fathers, mothers and, as we will see, even neighbours.

$49 \quad$ StAB BB 15.4. 1921951.

50 Göttsch (1995); Rublack (1998); Nolde (2003).

51 Spierenburg (2008, p. 224).

52 Spierenburg proposes to situate violent acts on axes of "impulsive-rational and ritual-instrumental". A robbery, for example, would be rational and instrumental whereas a tavern brawl would be impulsive and ritual. However, Spierenburg mentions that the rising numbers of "homicides on intimate" are difficult to place on these axes (1994, pp. 704-705). 
Second, the fatalistic crimes had a relatively long prehistory. In the majority of the cases, the perpetrator directly threatened the future victim or announced his or her plans to a third party prior to the crime. The desperate menace was an ultimatum. As an upcoming event threatened to change the perpetrator's life for the worse, the menace was a last call to turn things around. Almost always, the perpetrators not only threatened to kill the victims but also themselves. Once the threats were ignored and the perpetrators' fate turned against them, they single-handedly decided to take action. In the eyes of the perpetrator, she or he and the victim should share a common fate and die together.

This brings us to the third feature. Fatalistic perpetrators meant to kill and the crime was not only announced but also premeditated. Thus, fatalistic violence was always unilateral. There was no arguing, quarrelling or fighting immediately before the murder or murder attempt. This corresponds with the fact that fatalistic perpetrators typically used handguns that were often bought for the purpose of the crime. However, as these handguns were often of poor quality and the perpetrators had no experience as killers, the majority of the victims survived fatalistic murder attempts.

The fourth feature draws on the specific narratives of the fatalistic perpetrators which differ fundamentally from other criminals' stories. Unlike participants in sociable violence, fatalistic perpetrators spoke frankly about their feelings and informed the examining magistrates about their troubled mental state before, during, and after the violent act. Although they were often socially marginalized and economic failures, material difficulties, for example the threat of unemployment or of losing their lodgings, are present only as contexts. Instead psychological and subjective notions focus on the inner life of the perpetrator. Emotional disturbance, such as excitement, despondency, or jealousy are constituent parts of fatalistic narratives. Furthermore, it is not only the content of the story that is special, since the narratives possess a particular structure. The narrative contains a subjective monologue. Unlike in sociable violence and traditional domestic quarrels, fatalistic perpetrators' narratives document a seemingly inevitable personal tragedy. From a certain point onward, the perpetrator is the only actor in the story. Step by step, their fate becomes unbearable. The crime finally marks the endpoint of a continuous decline. Fatalistic perpetrators did not think any further than the crime itself. Trapped in fatalism, their future did not matter. This is underlined by the fact that fatalistic violence was often followed by a suicide attempt. ${ }^{53}$

The subjective nature of the narratives marks a significant difference from the narratives of sociable violence, which stress the interactive character of the event. Moreover, they also differ from the stories of traditional domestic quarrels and fights where the material and symbolical world of the family and household is at the centre of the stories. Men who beat their wives or children without any intention of killing them only rarely spoke about their emotions. Instead, they legitimated the use of violence because their wives or children had failed to respect their authority as husbands and fathers. Their narratives trivialize violence and enumerate the victims' misconduct which, in the perpetrators' view, provoked the violent outburst.

53 It is very likely that some fatalistic perpetrators actually killed themselves after the crime. Hence, the number of fatalistic homicides is probably higher than the juridical register indicates. 
We argue that, from a spatial perspective, the space of fatalistic violence was the troubled subjectivity or inner life of the perpetrator. Of course, the vast majority of all victims of fatalistic violence were spouses, lovers, and the perpetrator's own children. Lovers and family members were more likely to be victims of fatalistic crimes since the family and love relationships were coded as intimate and emotional spaces in the rising middle class culture ${ }^{54}$ Here, it was most likely that modern Westerners experienced a subjective crisis. However, personal tragedies could also be triggered by causes other than failed marriage or unhappiness in love as the following rather peculiar case example illustrates.

In March of 1909, the 45-year-old locksmith Johann Spillmann complained about the constant snoring of his roommate Lorenzo Pesenti, a 46-year-old Italian bricklayer: "Because I wasn't able to sleep, I could hardly work". Furthermore, he reported that he had trouble eating because of his "anger" and he had lately suffered from "headaches" which he related to his insomnia. Spillmann complained to his landlady and asked her to throw Pesenti out. As she ignored his requests and, instead, cancelled his own rental contract, he decided to take action. On a Saturday evening, after another sleepless night, he told the landlady's son that if Pesenti's rental contract was not cancelled too, he would shoot the bastard and then himself. He locked the room and waited on his bed with his army rifle next to him. When Pesenti returned home later that evening and tried to enter the room, Spillmann loaded his rifle and shot him through the locked door. ${ }^{55}$

Although the case example is exceptional and, at first sight, very different from the ones presented above, it nonetheless displays the four features of fatalistic violence. Spillmann detested Pesenti for his snoring. His strong feelings towards his roommate built up over an extended time period, and the killing was not a simple spontaneous reaction. Notwithstanding his constant anger, Spillmann never challenged Pesenti to fight, as the traditional tavern brawlers would have done. Instead, he announced the intention to kill himself and his victim. As with all fatalistic perpetrators, he planned the murder. Furthermore, his narrative contains a personal tragedy, which, according to Spillmann, was caused by insomnia. Pesenti's snoring was at the root of his decline. For Spillmann, the cancellation of the rental contract finally was a life-changing event. His roommate, who he hated so passionately, should share his fate and die with him.

\section{The increase of fatalistic violence}

Swiss cities were not the only places in the Western world where fatalistic violence occurred. Arguably, it increased in all Western societies during the nineteenth century. Spierenburg describes a homicide from Amsterdam during the Enlightenment that already had features of fatalistic violence. In 1775, the unsuccessful poet and actor Johannes van Gogh fell into a rage and killed his lover with a knife. She was a prostitute with whom he lived in an on-off relationship. Van Gogh had originally intended to kill himself in the presence of his beloved. Spierenburg argues that Van Gogh was an early follower of enlightened romanticism. ${ }^{56}$ In the USA, lovers started

\footnotetext{
$54 \quad$ See Trepp (1996); Luhmann (1986).

55 StAB BB 15.4. 1848582.

56 Spierenburg (2004, pp. 117-197).
} 
to kill their ex-sweethearts more frequently from the 1830s and 1840s onwards. In the same period, the rate of family homicide in the USA rose significantly. In the city of Chicago the "domestic homicide rate" constantly increased from the mid1870s onwards. In the late 1890s, it had overtaken the decreasing "brawl homicide rate" and it continued to grow. The numbers of children murdered by despondent fathers increased sharply after $1895 .{ }^{57}$ By reviewing the qualitative source material presented in American studies, it becomes obvious that fatalistic violence was one cause, if not the main cause, of this rise.$^{58}$ In Paris, cases that match the four features of fatalistic violence are well documented for the $1870 \mathrm{~s} .{ }^{59}$ Already at this time, fatalistic violence was not solely a metropolitan phenomenon since it occurred in the industrial north of the country too. By the 1870 s, the contexts of family murder (including of non-married partners) had changed dramatically in the Département du Nord. While early nineteenth-century disputes which led to killings of relatives were due to quarrels over material issues such as patrimony and property, family murder in the last decades of the century had changed to "crimes of passion" which were triggered by the perpetrators' emotional disturbance rather than directly by a dispute over material issues. As a consequence, spousal and romance homicide became the most frequent subtypes of family homicide. ${ }^{60}$

\section{DOUBLE IMPACT OF MIDDLE CLASS HABITUS ON INTERPERSONAL VIOLENCE}

Certainly, only very few early nineteenth and twentieth century Westerners effectively committed a fatalistic crime. However, the above-mentioned studies on interpersonal violence after 1800 support our data from Basel and Berne indicating that the prominence of fatalistic violence is linked to modernity. In Berne, the increase of fatalistic violence follows a period of relatively late industrialization from the 1890s onwards and falls within a period of rapid population growth and urbanization. ${ }^{61}$ Not only did it occur in the modern city, but the very character of fatalistic violence was modern. Just as sociable violence was part of a 'habitus' of honour, fatalistic violence was part of the specific modern habitus. ${ }^{62}$ While living in a modern city, ordinary people's mode of living and thinking changed. The strong feelings towards the victim, the idea of a life-changing biographical event, the intention to kill, and the emotional and subjective monologue unveil a new habitus in the context of violence. It was based on the individualistic experience of life. At the centre of this habitus is now no longer honour but subjectivity. For Bourdieu, honour can only be generated by concrete communication or interaction.

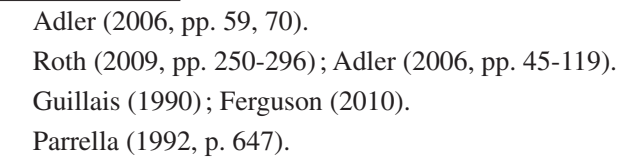

61 Berne approximated to the average development pattern of medium-sized European cities in the late nineteenth century. Bähler (2003, p. 16), Pfister (1995, pp. 144-148).

62 Both, Elias (1997, p. 326) and Bourdieu (2004, pp. 72-95) use the sociological concept of 'habitus' to link individual and social structures. The English version of Elias' Civilizing Process (1982b, p. 231) does not use the term 'habitus' but instead translates it to "manners" and "personality structures". 
The same applies to sociability according to Simmel. Thus, sociable violence was a dialectic and interactive game in which the players could collectively experience honour. Fatalistic violence, however, was entirely different. The monologuenarrative and the unilateral use of violence expose the individualistic and subjective character of fatalistic violence. Fatalistic perpetrators experienced their subjectivity individually ${ }^{63}$

Furthermore, honour and subjectivity differ in another respect: honour was relevant on the spur of the moment as the narratives of the brawlers show. Fatalistic perpetrators, by contrast, saw their crime in a much wider perspective. As mentioned above, the fatalistic crime is described as the consequence of a continuous personal tragedy in the life of the perpetrator. Fatalistic perpetrators saw their hopes and dreams vanish; and their fatalism called for action. Therefore, their crimes shed light on the importance of love, marriage, family, and work as constituent parts of a modern subjectivity. ${ }^{64}$ When one of these components was endangered, modern Westerners could experience a crisis; and some of them could not stand their fate any longer.

Spierenburg notes that "tension-related intimate homicides [...] probably increased since the eighteenth century". As already mentioned, he distinguishes this type of intimate violence from more traditional hierarchy-related punishments that got out of hand. Yet, it would be "unclear [...] how this increase links up with the trajectory of civilizing processes". ${ }^{65}$ The concept of fatalistic violence sheds new light on this question. Fatalistic perpetrators in many ways resemble the 'civilized' individual described by Elias in the Civilizing Process. In their monologue narratives they portrayed themselves as "homo clausus", stressing their subjective views, choices, and suffering. Elias explains that, in modernity, the "homo clausus, a little world in himself who ultimately exists quite independently of the great world outside, determines the image of man in general" ${ }^{66}$ Hence, modern and, to use Elias' terminology, civilized, Westerners had their own particular violent behaviour which cannot be explained as a leftover practice from the archaic or uncivilized past. It seems as if the civilized society has generated its own type of violence.

The strong notions of subjectivity which are typical of both the concept of homo clausus and of fatalistic violence correspond with the middle class habitus that established itself in all Western societies from the Enlightenment onwards. The increase of fatalistic violence in the nineteenth and especially in the early twentieth century was due to the formation and expansion of a middle class habitus. In 1911, one hundred and twenty years after a poet and actor killed his ex-girlfriend, an ordinary journeyman cobbler would try the same thing. More and more Westerners incorporated the mores of the new elites. ${ }^{67}$

\footnotetext{
63 On subjectivity as a modern habitus see Reckwitz (2006 pp. 9-31).

64 Reckwitz (2006, pp. 55-62)

65 Spierenburg (2008, p. 224); see also Spierenburg (1994, pp. 705-706).

66 Elias (1982b, p. 249).

67 The middle class habitus is not the same as the middle class. While habitus is a socio-cultural, class is a socio-economic category. The concept of habitus is based on the cultural analysis of actions or practices (such as sociable or fatalistic violence). The concept of class is merely based on the economic resources of a person. Indeed, the middle class habitus seems to have had a special attraction to lower ranks of Swiss society. A proletarian working class culture was a marginal phenomenon. The working class in the beginning was politically linked to left wing currents of the liberal movement
} 
Of course, social changes did not happen overnight. Steady demographic growth in Basel and Berne throughout the nineteenth century led to new complexity in the cities. Social differentiation merged with the disintegration of traditional forms of economy. Therefore, the spread of the middle class habitus was also fostered by the dissolution of the estate-based society. ${ }^{68}$ The gradual unfolding of middle class society and the market economy advanced new modes of socialization and association. The society in nineteenth-century Switzerland was not merely characterized by estates and guilds but growing numbers of voluntary associations gave nineteenth-century Swiss urban societies a new look. ${ }^{69}$ The transformation of nineteenth-century society led to the loosening of traditional social bonds and limited horizontal social control.

This brings us back to sociable violence. We argue that the very same middle class habitus not only favoured fatalistic violence but also led to the decline of sociable violence. As Eibach has shown for eighteenth-century Frankfurt, upperclass burghers and patricians solved disputes about honour in non-violent ways. He states that urban elites gradually incorporated a middle class habitus. ${ }^{70}$ And although the duel experienced a partial renaissance among the European elites in the last decades of the nineteenth century, the data from Basel shows that there was a growing tendency towards non-violent conflict settlement. In the nineteenth century, people from the lower social stratum increasingly reported insults to the authorities instead of settling their conflicts violently. ${ }^{71}$

In nineteenth and twentieth century Basel and Berne, only in the sociable space of the lower stratum was honour still disputed violently. According to Simmel, sociability is relatively detached from society. This might explain why the premodern violent game of honour persisted as social practice in Berne until the beginning of the twentieth century. The artificial world of the taverns had its own order and patterns of behaviour. Here, violence continued to be an integral part of communication. However, Simmel also stresses that sociability is only relatively detached from society. Hence, the sociability of the lower stratum in Berne was touched by the emergence of middle class society. Paradoxically, at first, the pacification of honour had a contrary influence on sociable violence. This was due to a loosening of traditional fighting rituals when lower stratum sociability was pushed to the margins of a society. As a consequence, at least in Berne, brawlers used knives in a more dangerous manner to defend themselves. Therefore, brawling became more lethal in the Swiss capital. This evidence supports the view of cultural historians who stress that in honour societies, although violent behaviour is a part of everyday communication and interaction, violence is not completely affective or uncontrolled as it is culturally and socially patterned.

Up to 1900, libel and slander cases were numerous in the court records from Basel and Berne. Only after the turn of the century, does their decrease indicate that the

and later on oriented to social democratic ideas. Thus, there was no distinctive proletarian culture of violence as identified by Jessen in industrial centres of Germany in the second half of the nineteenth century. For this point see Hettling (1998, pp. 240-244, 256); Hettling (1999, pp. 348-350); Degen (2009); Müller (2010); Jessen (1992).

69 Erne, Gull (2013).

70 Eibach (2009, p. 203).

71 See footnote 36 . 
importance of honour to assert personal status generally declined..$^{72}$ Simultaneously, the absence of reports on severe sociable violence and the drop in reports on assault and battery manifest that finally the sociability of lower stratum urban youths also became more peaceful or at least far less dangerous. Young men from Berne stopped playing the bloody and potentially lethal game of honour as they incorporated middle class mores.

Paradoxically, the very last case of sociable homicide from our Bernese sample helps to illustrate this change. In 1911, Emil Leuenberger was on his way home, after spending Saturday night at various taverns in the city centre. Suddenly, he had a rather bizarre conversation as a group of other youths crossed his path: "One of the gentlemen struck my arm at my left elbow, whereupon I said 'pardon monsieur' and the other replied 'pardon aussi'." What is surprising is not so much the apologies or the non-violent settlement of the incidents, since young men knew how to avoid a fight, but the use of polite forms such as gentlemen and monsieur, and, moreover, the use of French. Neither, "monsieur" Leuenberger, a 22-year-old master painter, nor the "gentlemen" Bürki, a 31-year-old steam locomotive fireman, were either francophone or bourgeois. They belonged to the city's lower stratum. Of course, things did not come to an end at this point. Leuenberger's acquaintance, the 23-yearold hired hand, Arnold Brunner, intervened by challenging Bürki. From there on, the procedure became quite traditional: Brunner attacked Bürki's companion Karl Jost, a 25-year-old book keeper. Thereafter, Jost floored Brunner. After this harmless incident, Bürki and Jost continued on their way home, but Brunner and his brother soon caught up with them. Then, something strange happened. Brunner recounted how he challenged Jost: "Me and you, we want to settle things, but not that the others intervene.' He answered: 'Fair enough, I do not fear you; let's go, come on.' I replied: 'good, let's go'". Thereafter, they took off their jackets and began to box. The fight did not last for long. Halfway through, the inferior Brunner stealthily pulled out his pocket knife and stabbed Jost to death. ${ }^{73}$

Perhaps, it was more than a coincidence that the spontaneous duel took place in front of the city's university building since students used to settle conflicts in a highly standardized manner. ${ }^{74}$ Although Brunner was not willing or capable of following these standards, the example shows that young working class men increasingly embraced middle class forms of conduct. Speaking politely and performing a formalized boxing duel ${ }^{75}$ were elements of modern middle class culture. When Simmel, a middle class man himself, wrote his essay on sociability in 1917, he used small talk and flirting to demonstrate the sociology of sociability. It seems that young men of the early twentieth century increasingly wanted to flirt and fall in love rather

72 For Basel see footnote 36. In the county of Berne, between 1852 and 1944, the criminal court dealt with 21 cases of libel ("Ehrverletzung", "Ehrverletzung durch die Presse", or "Pressinjurie"); all of them before 1905, see StAB BB. 15. 4. $503 \&$ \& 504. The same tendency can be observed on the level of the lower courts between 1880 and 1940. We counted slander cases ('Ehrverletzung', 'Ehrbeleidigung') for every fifth year. In 1880, 6 persons living in the county of Berne were accused of slander; in $1885: 6 ; 1890: 0 ; 1895: 11 ; 1900: 8 ; 1905: 3 ; 1910: 1 ; 1915: 0 ; 1920: 3 ; 1925: 2$; $1930: 1 ; 1935: 1 ; 1940: 1$. StAB XV 1123 and 1124.

73 StAB BB 15. 4. 19371018.

74 Frevert (1998, pp. 48-60).

75 In nineteenth century England, boxing and other forms of formalized fighting made fighting less dangerous. Muchembled (2012, p. 222). 
than fight for honour. And, some of this flirting might have marked the beginning of a personal tragedy which ended in a fatalistic crime.

Why lethal brawling has returned as a social fact in present-day Berne is a question for future research. In Switzerland, male homicide rates started to increase again in the 1960s. ${ }^{76}$ This fact might give a hint as to when and at what point fighting in public spaces regained importance. Perhaps the second wave of rapid urbanization in the 1960s had a less favourable impact on the violent behaviour of lower stratum urban youths than the one around 1900; and maybe it is no coincidence that, in the same decade, middle class mores experienced a major crisis and alternative subcultural identities started to spread. ${ }^{77}$

Maurice Cottier Universität Bern Historisches Institut Unitobler Längassstrasse 49 CH - 3000 Bern 9 maurice.cottier@iash.unibe.ch

Silvio Raciti Universität Bern Noflenstrasse 23 CH - 3116 Kirchdorf BE silvio.raciti@hist.unibe.ch

\section{REFERENCES}

\section{Primary sources}

Strafgesetzbuch für den Kanton Bern, Bern, 1866.

\section{Secondary sources}

Adler, J.S., First in Violence, Deepest in Dirt. Homicide in Chicago 1875-1920, Cambridge, Harvard Univ. Press, 2006.

Arni, C., Entzweiungen. Die Krise der Ehe um 1900, Köln, Böhlau, 2004.

Bähler, A., Von der Altstadt in der Aareschlaufe zur Stadtregion. Stadtentwicklung, Wohnungsbau, städtische Versorgungsnetze und Verkehr, in Barth, R. et al. (Eds), Bern - die Geschichte der Stadt im 19. und 20. Jahrhundert. Stadtentwicklung, Gesellschaft, Wirtschaft, Politik, Kultur, Bern, Stämpfli, 2003, pp. 11-45.

Belsey, C., The Poverty of (New) Historicism, in Barker, S. Gill, J. (Eds), Literature as History. Essays in Honour of Peter Widdowson, London, Continuum, 2010, pp. 7-17.

Bieri, O., Unterschiedliche Verlaufsmuster von Homizidraten im Zeitraum 1877 bis 1995 , in Eisner, M., Manzoni, P. (Eds), Gewalt in der Schweiz. Studien zu Entwicklung, Wahrnehmung und staatlicher Reaktion, Chur, Rüegger, 1998, pp. 41-65.

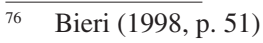

77 Because of increasing violence in Swiss cities since the 1960s, Eisner asks if the civilized city has come to an end. Eisner (1997). 
Bourdieu, P., Outline of a Theory of Practice, Cambridge, Cambridge Univ. Press, 2004.

Bouvier, J., The Wolters Kluwer Bouvier Law Dictionary, New York, Wolters Kluwer Law \& Business, 2011.

Cottier, M., Gewaltkultur im öffentlichen Raum des Amtsbezirks Bern 1861-1873, Schweizerische Zeitschrift für Kriminologie, 2009a, 2, pp. 34-48.

Cottier, M., Gesellige, häusliche und fatale Gewalt im Amtsbezirk Bern 1893-1927, Bern, unpublished master thesis, Univ. Bern, 2009b.

Dinges, M., Der Maurermeister und der Finanzrichter. Ehre, Geld und soziale Kontrolle im Paris des 18. Jahrhunderts, Göttingen, V\&R, 1994.

Dinges, M., Die Ehre als Thema der historischen Anthropologie. Bemerkungen zur Wissenschaftsgeschichte und zur Konzeptualisierung, in Schreiner, K., Schwerhoff, G. (Eds), Verletzte Ehre. Ehrkonflikte in Gesellschaften des Mittelalters und der Frühen Neuzeit, Köln, Böhlau, 1995, pp. 29-62.

Eibach, J., Frankfurter Verhöre. Städtische Lebenswelten und Kriminalität im 18. Jahrhundert, Paderborn, Schöningh, 2003.

Eibach, J., Gibt es eine Geschichte der Gewalt? Zur Praxis des Konflikts heute, in der Vormoderne und im 19. Jahrhundert, in Habermas, R., Schwerhoff, G. (Eds), Verbrechen im Blick. Perspektiven der neuzeitlichen Kriminalitätsgeschichte, Frankfurt, Campus, 2009, pp. 182-218.

Eisner, M., Das Ende der zivilisierten Stadt? Die Auswirkungen von Modernisierung und urbaner Krise auf Gewaltdelinquenz, Frankfurt, Campus, 1997.

Elias, N., The Civilizing Process, vol. 1, New York, Pantheon, 1982a.

Elias, N., The Civilizing Process, vol. 2, New York, Pantheon, 1982b.

Elias, N., Über den Prozess der Zivilisation, Bd. 1, Frankfurt, Suhrkamp, 1997.

Ferguson, E., Gender and Justice. Violence, Intimacy, and Community in Fin-de-Siècle Paris, Baltimore, John Hopkins Univ. Press, 2010.

Frank, M., Ehre und Gewalt im Dorf der Frühen Neuzeit. Das Beispiel Heiden (Grafschaft Lippe) im 17. und 18. Jahrhundert, in Schreiner, K., Schwerhoff, G. (Eds), Verletzte Ehre. Ehrkonflikte in Gesellschaften des Mittelalters und der Frühen Neuzeit, Köln, Böhlau, 1995, pp. 320-338.

Frevert, U., The Taming of the Noble Ruffian. Male Violence and Duelling in Early Modern and modern Germany, in Spierenburg, P. (ed.), Men and Violence. Gender, Honor, and Rituals in Modern Europe and America, Columbus, Ohio State Univ. Press, 1998, pp. 3763.

Goldberg, A., Honor, Politics, and the Law in Imperial Germany, 1871-1914, New York, Cambridge Univ. Press, 2010.

Göttsch, S., Vielmahls aber hätte sie gewünscht, einen anderen Mann zu haben. Gattenmord im 18. Jahrhundert, in Ulbricht, O. (ed.), Von Huren und Rabenmüttern. Weibliche Kriminalität in der Frühen Neuzeit, Köln, Böhlau, 1996, pp. 313-334.

Gschwind, F., Bevölkerungsentwicklung und Wirtschaftsstruktur der Landschaft Basel im 18. Jahrhundert. Ein historisch-demographischer Beitrag zur Sozial- und Wirtschaftsgeschichte mit besonderer Berücksichtigung der langfristigen Bevölkerungsentwicklung von Stadt (seit 1100) und Landschaft (seit 1500) Basel, Liestal, Kantonale Drucksachenund Materialzentrale, 1977.

Guillais, J., Crimes of Passion, New York, Routledge, 1990.

Gurr, T.R., Historical Trends in Violent Crime. A Critical Review of Evidence, Crime and Justice, 1981, 3, pp. 295-353.

Hettling, M., Bürgerlichkeit. Eine ungesellige Geselligkeit, in Hettling, M. et al. (Eds), Eine kleine Geschichte der Schweiz. Der Bundesstaat und seine Traditionen, Frankfurt, Suhrkamp, 1998, pp. 227-264. 
Hettling, M., Politische Bürgerlichkeit. Der Bürger zwischen Individualität und Vergesellschaftung in Deutschland und der Schweiz von 1860 bis 1918, Göttingen, V\&R, 1999.

Inhetveen, K., Gesellige Gewalt. Ritual, Spiel und Vergemeinschaftung bei Hardcorekonzerten, in Von Trotha, T. (Ed.), Soziologie der Gewalt, Opladen, Westdeutscher Verlag, 1997, pp. 235-260.

Jessen, R., Gewaltkriminalität im Ruhrgebiet zwischen bürgerlicher Panik und proletarischer Subkultur (1870-1914), in Kift, D. (Ed.), Kirmes-Kneipe-Kino. Arbeiterkultur im Ruhrgebiet zwischen Kommerz und Kontrolle (1850-1914), Paderborn, Schöningh, 1992, pp. 226-255.

Ludwig, U., Von Scherzen und Duellen. Wettkampfspiele als Typus von Ehrkonflikten im schwedisch-pommerschen Offizierskorps, Zeitschrift für historische Forschung, 2011, 38, pp. 371-403.

Ludwig, U., Krug-Richter, B., Schwerhoff, G. (Eds), Das Duell. Ehrenkämpfe vom Mittelalter bis zur Moderne, Konstanz, UVK, 2012.

Luhmann, N., Love as Passion. The Codification of Intimacy, Cambridge, Polity, 1986.

Muchembled, R., La violence au village. Sociabilité et comportements populaires en Artois du XV au XVII siècle, Bruxelles, Brepols, 1989.

Muchembled, R., A History of Violence, Cambridge, Polity, 2012.

Nolde, D., Gattenmord. Macht und Gewalt in der frühneuzeitlichen Ehe, Köln, Böhlau, 2003.

Parrella, A., Industrialization and Murder. Northern France 1815-1904, Journal of Interdisciplinary History, 1992, 22, 4, pp. 627-654.

Pfister, C., Im Strom der Modernisierung. Bevölkerung, Wirtschaft und Umwelt im Kanton Bern, 1700-1914, Bern, Haupt, 1995.

Raciti, S., Männlichkeit, Geselligkeit und Widersetzlichkeit. Gewaltdelinquenz in der Stadt der ersten Hälfte des 19. Jahrhunderts. Das Beispiel Basel, Bern, unpublished master thesis, Univ. Bern, 2006.

Reckwitz, A., Das hybride Subjekt. Eine Theorie der Subjektkulturen von der bürgerlichen Moderne zur Postmoderne, Weilerswist, Velbrück, 2006.

Roth, R., American Homicide, Cambridge, Belknap Press of Harvard Univ. Press, 2009.

Rublack, U., Magd, Metz'oder Mörderin. Frauen vor frühneuzeitlichen Gerichten, Frankfurt, Fischer, 1998.

Sarasin, P., Stadt der Bürger. Bürgerliche Macht und städtische Gesellschaft. Basel 18461914, Göttingen, V\&R, 1997.

Schreiner, K., Schwerhoff, G. (Eds), Verletzte Ehre. Ehrkonflikte in Gesellschaften des Mittelalters und der Frühen Neuzeit, Köln, Böhlau, 1995.

Schuster, P., Eine Stadt vor Gericht. Recht und Alltag im spätmittelalterlichen Konstanz, Paderborn, Schöningh, 2000.

Schwerhoff, G., Köln im Kreuzverhör. Kriminalität, Herrschaft und Gesellschaft in einer frühneuzeitlichen Stadt, Bonn, Bouvier, 1991.

Simmel, G., The Sociology of Sociability, American Journal of Sociology, 1949, 55, 3, pp. 254-261.

Simon-Muscheid, K., Gewalt und Ehre im spätmittelalterlichen Handwerk am Beispiel Basels, Zeitschrift für historische Forschung, 1991, 18, pp. 1-31.

Spierenburg, P., Faces of Violence. Homicide Trends and Cultural Meanings. Amsterdam, 1431-1816, Journal of Social History, 1994, 27, 4, pp. 701-716.

Spierenburg, P., Knife Fighting and Popular Codes of Honor in Early Modern Amsterdam, in Spierenburg, P. (ed.), Men and Violence. Gender, Honor, and Rituals in Modern Europe and America, Columbus, Ohio State Univ. Press, 1998, pp. 103-127. 
Spierenburg, P., Written in Blood. Fatal Attraction in Enlightenment Amsterdam, Columbus, Ohio State Univ. Press, 2004.

Spierenburg, P., A History of Murder. Personal Violence in Europe from the Middle Ages to the Present, Cambridge, Polity, 2008.

Töngi, C., Um Leib und Leben. Gewalt, Konflikt, Geschlecht im Uri des 19. Jahrhunderts, Zürich, Chronos, 2004.

Trepp, A., Sanfte Männlichkeit und selbständige Weiblichkeit. Frauen und Männer im Hamburger Bürgertum zwischen 1770 und 1840, Göttingen, V\&R, 1996.

Walz, R., Agonale Kultur im Dorf der Frühen Neuzeit, Westfälische Forschungen, 1992, 42, pp. 215-251.

Wettmann-Jungblut, P., Gewalt und Gegen-Gewalt. Gewalthandeln, Alkoholkonsum und die Dynamik von Konflikten anhand eines Fallbeispiels aus dem frühneuzeitlichen Schwarzwald, in Eriksson, M., Krug-Richter, B. (Eds), Streitkulturen. Gewalt, Konflikt und Kommunikation in der ländlichen Gesellschaft (16.-19. Jahrhundert), Köln, Böhlau, 2003, pp. 17-58.

\section{Internet sources}

Degen, B., Arbeiterbewegung, in Historisches Lexikon der Schweiz, 2009 [http ://www.hlsdhs-dss.ch/textes/d/D16479.php] (visited 30.04.2013).

Erne, E., Gull, T., Vereine, in Historisches Lexikon der Schweiz, 2013 [http ://www.hls-dhsdss.ch/textes/d/D25745.php] (visited 30.04.2013).

Müller, F., Grütliverein, in Historisches Lexikon der Schweiz, 2010 [http ://www.hls-dhs-dss. ch/textes/d/D17397.php] (visited 30.04.2013).

Pfister, C. (ed.), Bernhist. Historisch-Statistische Datenbank des Kantons Bern, Bern, 19942006 [http://www.bernhist.ch/d/menu/ index.php] (visited 21.10.2012). 